\title{
Occurrence of Aculus mosoniensis (Ripka, 2014) (Acari; Prostigmata; Eriophyoidea) on tree of heaven (Ailanthus altissima Mill.) is expanding across Europe. First record in France confirmed by Barcoding
}

\author{
Javid Kashefi $\mathbb{D} \cdot$ B. Vidović $\cdot$ F. Guermache $\cdot$ \\ M. Cristofaro $\cdot$ M. C. Bon (i)
}

Received: 14 April 2021 / Accepted: 6 August 2021 / Published online: 2 November 2021

This is a U.S. government work and not under copyright protection in the U.S.; foreign copyright protection may apply 2021

Summary In May 2020, populations of Eriophyid mites were detected on tree of heaven, Ailanthus altissima Mill., in a recreative park in the city of Colombes, near Paris, and later in August and September in four locations, in Southern France. Morphological examination supplemented with sequencing data for the cytochrome c oxidase subunit I (COI) assigned all collected mites to a single species, Aculus

J. Kashefi $(\bowtie) \cdot$ F. Guermache · M. C. Bon

USDA-ARS-European Biological Control Laboratory,

810 Avenue du Campus International Agropolis,

34980 Montferrier le Lez, France

e-mail: jkashefi@ars-ebcl.org

F. Guermache

e-mail: fguermache@ars-ebcl.org

M. C. Bon

e-mail: mcbon@ars-ebcl.org

B. Vidović

Faculty of Agriculture, Department of Entomology and Agricultural Zoology, University of Belgrade, Nemanjina 6, 11080 Belgrade-Zemun, Serbia

e-mail: magud@agrif.bg.ac.rs

\section{Cristofaro}

The Biotechnology and Biological Control Agency (BBCA) Onlus, via Angelo Signorelli 105, 00123 Rome, Italy

e-mail: m.cristofaro55@gmail.com

M. Cristofaro

ENEA- SSPT BIOAG, via Anguillarese 301, 00123 Rome, Italy mosoniensis (Ripka) (Acari; Prostigmata; Eriophyoidea). This is the first record of this species in France and the first insights into its intraspecific variability based on a barcode dataset. In Europe, this species is considered one of the most promising biological control agents of tree of heaven. This new record provides encouraging evidence that the geographic occurrence of this species is expanding in Europe which may be indicative of its dispersal and establishment abilities, two key factors for a future biological control program.

Keywords Eriophyid mites - Invasive species · Mitochondrial DNA · Biological control $\cdot$ Europe

\section{Introduction}

Ailanthus altissima (Mill.) Swingle, 1916, commonly known as tree of heaven or Faux vernis du Japon, is a fast-growing deciduous tree, native to both northeast and central China, as well as Taiwan (Hu, 1979; Kowarik \& Säumel, 2007). This species was brought from China to Europe by the French missionary Pierre d'Incarville in the 1740s. Among Incarville's seed recipients, was Bernard de Jussieu, the Superintendent of the Jardin Royal des Plantes in Paris, in France. De Jussieu sowed a portion of the seeds and sent some of them to the Chelsea Physic Garden, in London 
(Swingle, 1916). By the 1840s, this species, valued for its fast-growing ability and its resistance to insect infestation and damage, was being widely planted as a shade tree for parks and public promenades in Europe, particularly in France and Italy (Shah, 1997).

Widely naturalized in Europe, tree of heaven has been included on the EPPO List of Invasive Alien Plants since 2004 (EPPO, 2021), and on the list of the 100 worst alien plant species in Europe (DAISIE European Invasive Alien Species Gateway 2012). The species is regulated in several EPPO countries and many countries outside EPPO including the USA (CABI, 2021; EPPO, 2019; Motard et al., 2015; Sladonja et al., 2015). Its invasiveness is primarily attributed to five traits 1) tolerance of extreme environmental conditions although tree of heaven typically occurs in humid habitats (Albright et al., 2010); 2) production of more than 200 allelopathic substances including the phytotoxic quassinoid ailantone (Heisey, 1996; Lin et al., 1995); 3) high seed production and viability of seeds with mature females bearing highly abundant wind-dispersed samaras (Landenberger et al., 2007; Wickert et al., 2017); 4) clonal proliferation with copious sprouting after cutting (Hu, 1979); 5) limitations of herbivores insects capable of suppressing this invasive tree (Ding et al., 2006; Kiviat, 2004; Sheppard et al., 2006). In France, A. altissima is typically restricted to urban and suburban habitats in temperate climates but it is also frequent in rural areas of meridional and Mediterranean climates (iNaturalist, 2021; Kowarik, 1983). In southern and southwestern France, $A$. altissima is increasingly invading vineyards and is apparently difficult to control, particularly along grapevine rows where mechanical control damages grapevine roots. In addition, in organic vineyards the use of herbicides is prohibited (EPPO, 2019; 2021). In many countries, management is largely dependent on the use of systemic (and non-selective) chemical herbicides and mechanical control, and clearly lacks a long-term and sustainable control. In Europe, as the approval of chemical herbicides including glyphosate, is facing severe restrictions if not an outright ban, there is a growing need to adopt more ecologically sound and sustainable strategies such as classical biological control (Sheppard et al., 2006).
In literature surveys of natural enemies of tree of heaven in China, Ding et al. (2006) listed 46 phytophagous arthropods, 16 fungi and one potyvirus to attack tree of heaven, some apparently causing significant damages. Included in the tree of heaven feeding arthropods are four Eriophyid mites species - Aculops ailanthi Lin et al., 1997, Aculops taihangensis Hong \& Xue, 2005, Aculus altissimae Xue \& Hong, 2005, and Aculus mosoniensis Ripka, 2014 (Ripka \& Érsek, 2014). The early synonymy between Aculops tailhangensis and Aculus mosoniensis suggested by de Lillo et al. (2017) based on morphological characters was supported by a high similarity between their internal transcriber spacer 1 sequences (Cristofaro \& de Lillo, 2019; Marini et al., 2021). In Europe, Aculus mosoniensis, first reported in Hungary (Ripka \& Érsek, 2014) and recently in Italy (de Lillo et al., 2017), and the vascular wilt pathogen, Verticillium dahlia, isolated in Italy (Pisuttu et al., 2020), are the only two potential European biological control agents of tree of heaven. Aculus mosoniensis forms dense populations mainly at the under surface of the leaflets of the young compound leaves, causing leaf edges to curl upwards and turn yellowish in color. Drying of the upper parts of the stem can be observed on heavily infested plants, and young plants can desiccate and loose leaves prematurely (Cristofaro \& De Lillo, 2019). In May 2020, as a part of an ongoing quest of USDA ARS to identify natural enemies of tree of heaven, weekly field observations were carried out in a recreative park in the city of Colombes, near Paris. One tree was found to display leaf rolling associated with an Eriophyid mite infestation, similar to that described by Ripka and Érsek (2014) in Hungary (Fig. 1). Leaf examination using a digital microscope (Dino-Lite Edge, Taipei, Taiwan, 100X magnification) confirmed the presence of eriophyid mites (Fig. 2). In follow up investigations, additional trees showed similar mite infestation symptoms. Since this first occurrence and later in the growing season, from August to September, four populations of eriophyid mites were found in different localities in Southern France. We here identify to species level all populations of Eriophyid mites sampled on tree of heaven in France by examining morphological characters. We also compare barcoding datasets obtained in these populations 


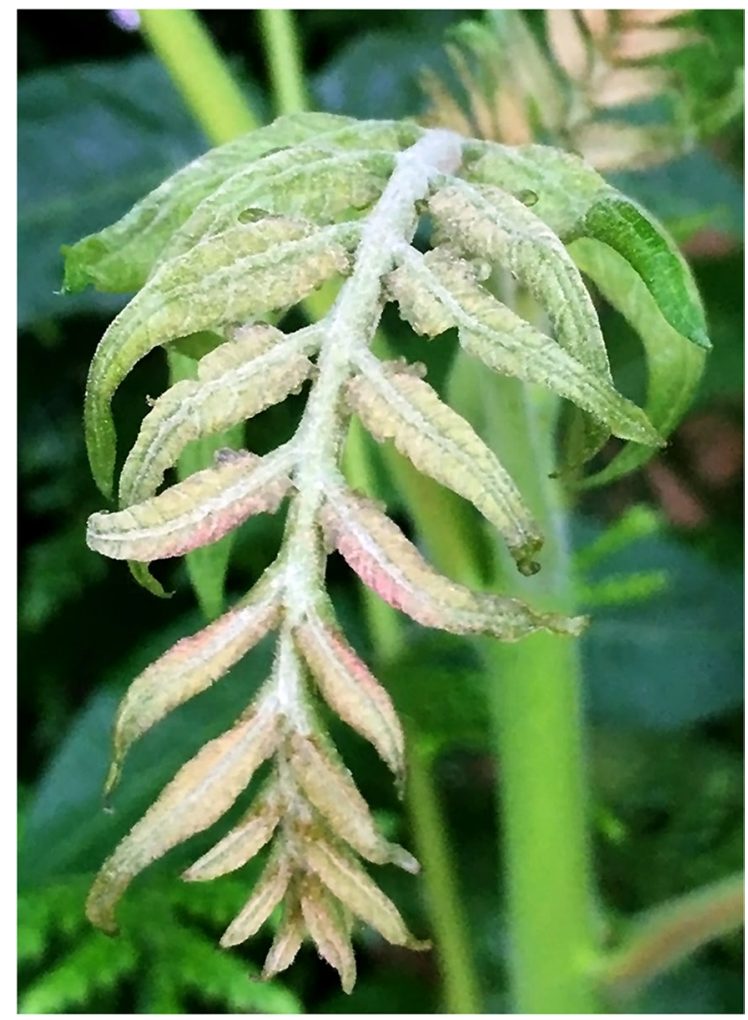

Fig. 1 Heavily infested A. altissima leaves

with barcodes (mitochondrial regions on the 5' end of the cytochrome c oxidase subunit I (COI)) of a $A$. mosoniensis Italian population which is used in an ongoing biological control program.

\section{Materials and methods}

Mite infested leaves were collected between May and September 2020 in different locations in France (Table 1) and preserved in $70 \%$ ethanol for morphological examination at the University of Belgrade, in Serbia and in $96 \%$ ethanol for molecular characterization at EBCL in France. For morphological identification, specimens were mounted in Keifer's F medium (Amrine \& Manson, 1996) and then examined using a Leica DMLS research microscope with phase-contrast. For molecular characterization of each population sampled, four to five

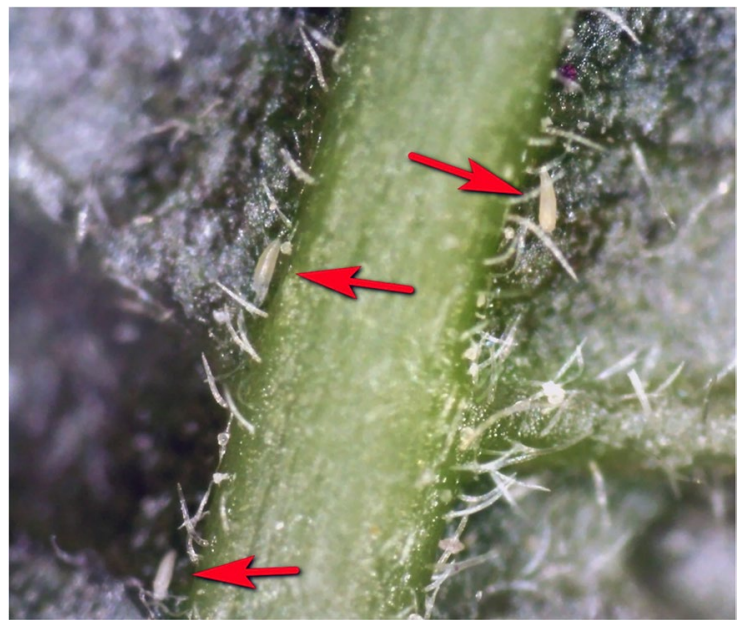

Fig. 2 Aculus mosoniensis mites on Tree of Heaven leaf

pools of 5 to 7 specimens were carefully removed off one leaf using a fine brush and examined under a stereomicroscope (Dino-Lite Edge, Taipei, Taiwan, $100 \mathrm{X}$ magnification). Each pool was subsequently placed into a $1.5 \mathrm{ml}$ Eppendorf LoBind collecting tube. Four pools of five A. mosoniensis specimens collected at a site near Roma in Italy were also processed following the same protocol (Table 1). After complete evaporation of the residual ethanol using Speed-Vac, 20 $\mu$ L of 1X PCR buffer (Qiagen, Hilden, Germany), $2 \mu \mathrm{L}$ of Proteinase K (Qiagen, Hilden, Germany $20 \mathrm{mg} / \mathrm{ml}$ ) and $20 \mu \mathrm{L}$ of GeneReleaser ${ }^{\circledR}$ (BioVentures, Inc., Murfreesboro, TN, USA) were added to the collecting tube which was incubated during $3 \mathrm{~h}$ at $56{ }^{\circ} \mathrm{C}$ using a Thermomix $® \mathrm{C}$ (Eppendorf, Hamburg, Germany). Following an incubation at $95{ }^{\circ} \mathrm{C}$ for $10 \mathrm{~min}$ to inactivate the Proteinase $\mathrm{K}$, the tube was centrifuged at $10,000 \mathrm{~g}$ for $5 \mathrm{~min}$ and the resulting supernatant was used immediately as DNA template for PCR or stored at $-24{ }^{\circ} \mathrm{C}$. PCR amplifications of the barcode region were performed in a total volume of $30 \mu \mathrm{L}$ containing $1 \times$ of CoralLoad PCR Kit (Qiagen), $0.2 \mu \mathrm{M}$ of each degenerate primer, LCO1490puc and $\mathrm{HCO} 2198$ puc, (Cruaud et al., 2010), $1 \mathrm{mM}$ of $\mathrm{MgCl}_{2}, 0.2 \mathrm{mg} / \mathrm{ml}$ of Bovine Serum Albumin, 1 Unit of Taq polymerase (Qiagen) and 3.0 $\mu \mathrm{L}$ of diluted template DNA. The thermal cycling program was as follows: $3 \mathrm{~min}$ at 
Table 1 Collection records of $A$. mosoniensis populations used in this study

\begin{tabular}{|c|c|c|c|c|c|}
\hline Sample ID & Locality/Country & $\begin{array}{l}\text { Name of the Collector/ } \\
\text { Agency }\end{array}$ & $\begin{array}{l}\text { Collection date } \\
\text { (dd/mm/yyyy) }\end{array}$ & GPS coordinates & $\begin{array}{l}\text { Barcode Genbank } \\
\text { Accession number }\end{array}$ \\
\hline TOHA2c & Cesano near Roma/Italy & $\begin{array}{l}\text { S. Barlattani; F. Marini/ } \\
\text { BBCA }\end{array}$ & 07/07/2020 & $42^{\circ} 03^{\prime} 50^{\prime}{ }^{\prime} \mathrm{N} 12^{\circ} 19^{\prime} 44^{\prime \prime} \mathrm{E}$ & MW892618 \\
\hline Italy 1 & Cesano near Roma/Italy & $\begin{array}{l}\text { S. Barlattani; F. Marini/ } \\
\text { BBCA }\end{array}$ & 07/07/2020 & $42^{\circ} 03^{\prime} 50^{\prime}{ }^{\prime} \mathrm{N} 12^{\circ} 19^{\prime} 44^{\prime \prime} \mathrm{E}$ & MW892618 \\
\hline Italy 3 & Cesano near Roma/Italy & $\begin{array}{l}\text { S. Barlattani; F. Marini/ } \\
\text { BBCA }\end{array}$ & 07/07/2020 & $42^{\circ} 03^{\prime} 50^{\prime}{ }^{\prime} \mathrm{N} 12^{\circ} 19^{\prime} 44^{\prime \prime} \mathrm{E}$ & MW892618 \\
\hline Italy5 & Cesano near Roma/Italy & $\begin{array}{l}\text { S. Barlattani; F. Marini/ } \\
\text { BBCA }\end{array}$ & $07 / 07 / 2020$ & $42^{\circ} 03^{\prime} 50^{\prime \prime} \mathrm{N} 12^{\circ} 19^{\prime} 44^{\prime \prime} \mathrm{E}$ & MW892618 \\
\hline Colombes 3 & Colombes/France & Javid Kashefi/EBCL & $05 / 26 / 2020$ & $48^{\circ} 55^{\prime} 23^{\prime \prime} \mathrm{N} 2^{\circ} 13^{\prime} 57^{\prime \prime} \mathrm{E}$ & MW892615 \\
\hline Colombes7 & Colombes/France & Javid Kashefi/EBCL & $05 / 26 / 2020$ & $48^{\circ} 55^{\prime} 23^{\prime \prime} \mathrm{N} 2^{\circ} 13^{\prime} 57^{\prime \prime} \mathrm{E}$ & MW892616 \\
\hline Colombes8 & Colombes/France & Javid Kashefi/EBCL & $05 / 26 / 2020$ & $48^{\circ} 55^{\prime} 23^{\prime \prime} \mathrm{N} 2^{\circ} 13^{\prime} 57^{\prime \prime} \mathrm{E}$ & MW892617 \\
\hline Colombes 9 & Colombes/France & Javid Kashefi/EBCL & $05 / 26 / 2020$ & $48^{\circ} 55^{\prime} 23^{\prime \prime} \mathrm{N} 2^{\circ} 13^{\prime} 57^{\prime \prime} \mathrm{E}$ & MW892616 \\
\hline Colombes 10 & Colombes/France & Javid Kashefi/EBCL & $05 / 26 / 2020$ & $48^{\circ} 55^{\prime} 23^{\prime \prime} \mathrm{N} 2^{\circ} 13^{\prime} 57^{\prime \prime} \mathrm{E}$ & MW892615 \\
\hline TOHA5 & Viols le Fort/France & Javid Kashefi/EBCL & 08/04/2020 & $\begin{array}{r}43^{\circ} 44^{\prime} 45.75^{\prime \prime} \mathrm{N} \\
3^{\circ} 42^{\prime} 31.27^{\prime \prime} \mathrm{E}\end{array}$ & MW892619 \\
\hline Viols le Fort1 & Viols le Fort/France & Javid Kashefi/EBCL & $08 / 04 / 2020$ & $\begin{array}{r}43^{\circ} 44^{\prime} 45.75^{\prime \prime} \mathrm{N} \\
3^{\circ} 42^{\prime} 31.27^{\prime \prime} \mathrm{E}\end{array}$ & MW892619 \\
\hline Viols le Fort 3 & Viols le Fort/France & Javid Kashefi/EBCL & $08 / 04 / 2020$ & $\begin{array}{r}43^{\circ} 44^{\prime} 45.75^{\prime \prime} \mathrm{N} \\
3^{\circ} 42^{\prime} 31.27^{\prime \prime} \mathrm{E}\end{array}$ & MW892619 \\
\hline Viols le Fort4 & Viols le Fort/France & Javid Kashefi/EBCL & $08 / 04 / 2020$ & $\begin{array}{r}43^{\circ} 44^{\prime} 45.75^{\prime \prime} \mathrm{N} \\
3^{\circ} 42^{\prime} 31.27^{\prime \prime} \mathrm{E}\end{array}$ & MW892619 \\
\hline TOHA6 & Manosque/ France & Javid Kashefi/ EBCL & 09/09/2020 & $\begin{array}{r}43^{\circ} 48^{\prime} 31.13^{\prime \prime} \mathrm{N} \\
5^{\circ} 48^{\prime} 47.45^{\prime \prime} \mathrm{E}\end{array}$ & MW892620 \\
\hline Manosque1 & Manosque/ France & Javid Kashefi/ EBCL & 09/09/2020 & $\begin{array}{r}43^{\circ} 48^{\prime} 31.13^{\prime \prime} \mathrm{N} \\
5^{\circ} 48^{\prime} 47.45^{\prime \prime} \mathrm{E}\end{array}$ & MW892620 \\
\hline Manosque3 & Manosque/ France & Javid Kashefi/ EBCL & 09/09/2020 & $\begin{array}{r}43^{\circ} 48^{\prime} 31.13^{\prime \prime} \mathrm{N} \\
5^{\circ} 48^{\prime} 47.45^{\prime \prime} \mathrm{E}\end{array}$ & MW892620 \\
\hline Manosque4 & Manosque/ France & Javid Kashefi/ EBCL & 09/09/2020 & $\begin{array}{r}43^{\circ} 48^{\prime} 31.13^{\prime \prime} \mathrm{N} \\
5^{\circ} 48^{\prime} 47.45^{\prime \prime} \mathrm{E}\end{array}$ & MW892620 \\
\hline TOHA7 & Vinon sur Verdon/France & Javid Kashefi/ EBCL & 09/10/2020 & $\begin{array}{r}43^{\circ} 43^{\prime} 50.87^{\prime \prime} \mathrm{N} \\
5^{\circ} 48^{\prime} 43.96^{\prime \prime} \mathrm{E}\end{array}$ & MW892621 \\
\hline Vinon1 & Vinon sur Verdon/France & Javid Kashefi/ EBCL & 09/10/2020 & $\begin{array}{r}43^{\circ} 43^{\prime} 50.87^{\prime \prime} \mathrm{N} \\
5^{\circ} 48^{\prime} 43.96^{\prime \prime} \mathrm{E}\end{array}$ & MW892621 \\
\hline Vinon2 & Vinon sur Verdon/France & Javid Kashefi/ EBCL & 09/10/2020 & $\begin{array}{r}43^{\circ} 43^{\prime} 50.87^{\prime \prime} \mathrm{N} \\
5^{\circ} 48^{\prime} 43.96^{\prime \prime} \mathrm{E}\end{array}$ & MW892621 \\
\hline Vinon5 & Vinon sur Verdon/France & Javid Kashefi/ EBCL & 09/10/2020 & $\begin{array}{r}43^{\circ} 43^{\prime} 50.87^{\prime \prime} \mathrm{N} \\
5^{\circ} 48^{\prime} 43.96^{\prime \prime} \mathrm{E}\end{array}$ & MW892621 \\
\hline TOHA8 & Sisteron/ France & Javid Kashefi/ EBCL & 09/10/2020 & $\begin{array}{r}44^{\circ} 10^{\prime} 15.21^{\prime \prime} \mathrm{N} \\
5^{\circ} 56^{\prime} 55.18^{\prime \prime} \mathrm{E}\end{array}$ & MW892622 \\
\hline Sisteron 1 & Sisteron/ France & Javid Kashefi/ EBCL & 09/10/2020 & $\begin{array}{r}44^{\circ} 10^{\prime} 15.21^{\prime \prime} \mathrm{N} \\
5^{\circ} 56^{\prime} 55.18^{\prime \prime} \mathrm{E}\end{array}$ & MW892622 \\
\hline Sisteron3 & Sisteron/ France & Javid Kashefi/ EBCL & 09/10/2020 & $\begin{array}{r}44^{\circ} 10^{\prime} 15.21^{\prime \prime} \mathrm{N} \\
5^{\circ} 56^{\prime} 55.18^{\prime \prime} \mathrm{E}\end{array}$ & MW892622 \\
\hline Sisteron4 & Sisteron/ France & Javid Kashefi/ EBCL & 09/10/2020 & $\begin{array}{r}44^{\circ} 10^{\prime} 15.21^{\prime \prime} \mathrm{N} \\
5^{\circ} 56^{\prime} 55.18^{\prime \prime} \mathrm{E}\end{array}$ & MW892622 \\
\hline
\end{tabular}




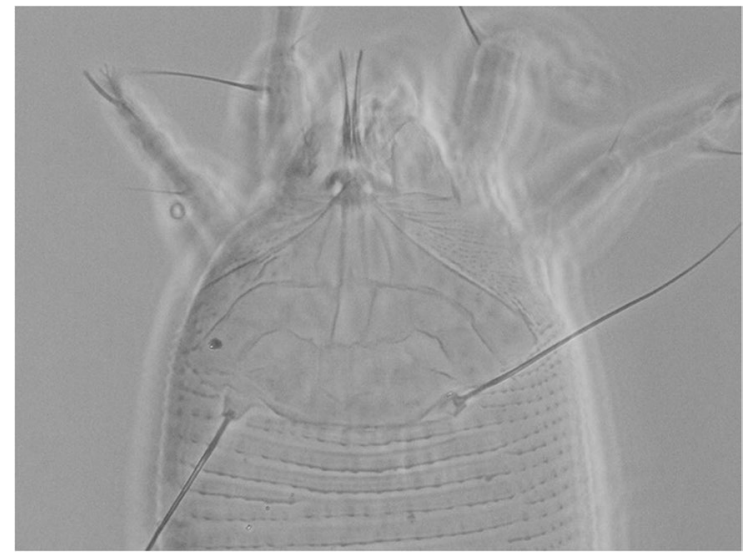

Fig. 3 Aculus mosiniensis-dorsal view of prodorsal shield (phase-contrast light microscope)

$94{ }^{\circ} \mathrm{C}, 40$ cycles of $30 \mathrm{~s}$ at $94^{\circ} \mathrm{C}, 30 \mathrm{~s}$ at $50{ }^{\circ} \mathrm{C}$, $1 \mathrm{~min}$ at $72{ }^{\circ} \mathrm{C}$ and a final extension of $10 \mathrm{~min}$ at $72{ }^{\circ} \mathrm{C}$. PCR products were sequenced in the forward and reverse direction using Sanger approach by Genoscreen at Lille, France. Sequences were translated into amino acids; the absence of stop codons was checked with Mega X (Kumar et al., 2018). Sequence alignment was performed using ClustalW (Higgins et al., 1994) as implemented in Mega X. Overall and pairwise distances between nucleotide sequences were calculated using Kimura's twoparameter model in Mega X.

\section{Results and discussion}

Mite specimens collected in the five locations in France were examined and determined to be Aculus mosoniensis based on qualitative and morphological characteristics of this species such as the design of prodorsal shield and the number of rays on tarsal empodium (Fig. 3) (de Lillo et al., 2017; Ripka \& Érsek, 2014). Barcode compliant sequences of 685 bp were successfully obtained for each pool of mites sampled and none of the characteristic evidence of numts was present in the sequences obtained. All different sequences obtained in each population have been deposited in Genbank database with accession numbers
Table 2 Kimura two-parameter distances (shown as percentages with SE estimates between mitochondrial DNA COI sequence pairs

\begin{tabular}{ll}
\hline Level & $\begin{array}{l}\text { Mean dis- } \\
\text { tance } \pm \text { SE } \\
(\%)\end{array}$ \\
\hline Within Colombes & $0.89 \pm 0.27$ \\
Within Italy & 0 \\
Within Southern France & 0 \\
Between Colombes and Italy & $0.89 \pm 0.29$ \\
Between Colombes and Southern France & $0.73 \pm 0.24$ \\
Between Italy and Southern France & $1.38 \pm 0.47$ \\
\hline
\end{tabular}

indicated in Table 1. At the time of writing, no barcode sequence data of A. mosoniensis or A. taihangensis was available in Genbank. Species identification was attempted by BOLD identification engine in Barcode of Life Data Systems (BOLD Systems v3), and all sequences including the Italian A. mosoniensis were assigned with similarity scores ranging from 98.6 to 99.6\% to A. taihangensis of Chinese origin All barcode sequences from southern France were $100 \%$ identical as well as all barcode sequences from Italy. In Colombes, we identified three haplotypes in the five pools analyzed. Genetic distances between the Italian A. mosoniensis and Colombes and southern France populations ranged from 0.89 to $1.388 \%$ (Table 2), which is low and compatible with the intraspecific distances reported in other eriophyid mite species such as Aceria tosichella Keifer (Skoracka et al., 2012a, b) and Abacarus denticulifer Chetverikov (Chetverikov et al., 2019).

\section{Concluding remark}

The presence of A. mosoniensis was confirmed in all sampled locations in France, which indicates that this mite is already established and largely distributed within France. To the best of our knowledge, this is the first report of A. mosoniensis in France. As this eriophyid mite is considered one of the most promising biological control agents of 


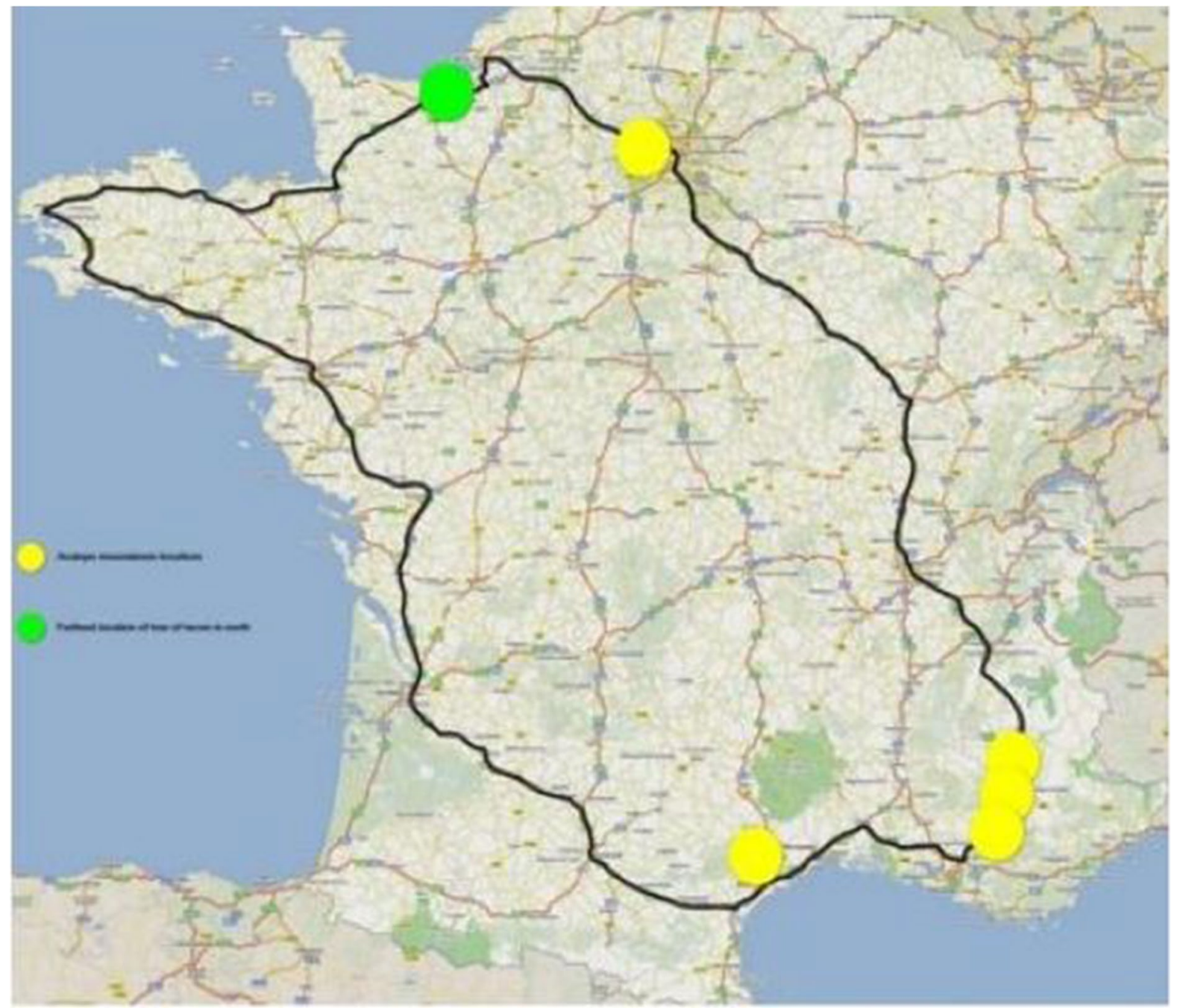

Map 1 Collection map and rout in France. Yellow dots=Aculops mosoniensis collection sites. Greece dot=Most northern location of Ailanthus altissima collection point

tree of heaven in Europe, this new record provides encouraging evidence that the geographic occurrence of this species is expanding in Europe, apparently always associated with the target weed, which may be indicative of its dispersal and establishment abilities, two key factors for a future biological control program (Map 1).

Acknowledgements Authors would like to thank Francesca Marini and Silvia Barlattani (BBCA) for their field and technical support. Mention of trade names or commercial products in this publication is solely for the purpose of providing specific information and does not imply recommendation or endorsement by the USDA; USDA is an equal opportunity provider and employer.

Author contribution Conceptualization, $\mathrm{MCB}$ and JK.; methodology, JK, FG and MC.; formal analysis, MCB and FG.; resources, JK and MC; writing — original draft preparation, JK, $\mathrm{MCB}$ and $\mathrm{MC}$; writing - review and editing, JK, MCB and MC.

\section{Declarations}

Conflict of interest The authors declare that they have no conflict of interest. 
Open Access This article is licensed under a Creative Commons Attribution 4.0 International License, which permits use, sharing, adaptation, distribution and reproduction in any medium or format, as long as you give appropriate credit to the original author(s) and the source, provide a link to the Creative Commons licence, and indicate if changes were made. The images or other third party material in this article are included in the article's Creative Commons licence, unless indicated otherwise in a credit line to the material. If material is not included in the article's Creative Commons licence and your intended use is not permitted by statutory regulation or exceeds the permitted use, you will need to obtain permission directly from the copyright holder. To view a copy of this licence, visit http://creativecommons.org/licenses/by/4.0/.

\section{References}

Albright, T. P., Chen, H., Chen, L., \& Guo, Q. (2010). The ecological niche and reciprocal prediction of the disjunct distribution of an invasive species: The example of Ailanthus altissima. Biological Invasions, 12(8), 2413-2427.

Amrine, J. W., \& Manson, D. C. M. (1996). Preparation, mounting and descriptive study of Eriophyoid mites. In E. E. Lindquist, M. W. Sabelis, \& J. Bruin (Eds.), World Crop pests: Eriophyoid mites Their biology, natural enemies and control (pp. 383-396). Amsterdam: Elsevier Science $\mathrm{BV}$.

CABI. (2021). Ailanthus altissima. In: Invasive Species Compendium. Wallingford, UK: CAB International. www. cabi.org/isc. Accessed 24th Mar 2021.

Chetverikov, P., Klimov, P., Letukhova, V., Ripka, G., \& Zukoff, S. (2019). Two new phyllocoptine species and new records of eriophyoid mites (Eriophyidae, Phyllocoptinae) from Crimea, with evaluation of the phylogenetic position of the new taxa using GenBank data. Systematic and Applied Acarology, 24, 882. https://doi.org/10.11158/ saa.24.5.11.

Cristofaro, M., \& De Lillo, E. (2019). La Pianta infestante Ailanthus altissima e studio della fattibilita di un programma di controllo biologico. Atti Accademia Nazionale Italiana di Entomologia Anno LXVII, 2019, 73-79.

Cruaud, A., Jabbour-Zahab, R., Genson, G., Cruaud, C., \& Couloux, A. (2010). Laying the foundations for a new classification of Agaonidae (Hymenoptera: Chalcidoidea), a multilocus phylogenetic approach. Cladistics, 26, 359-387.

DAISIE (2012). Delivering Alien Invasive Species Inventories for Europe. Invasive Alien Species Fact Sheet - Ailanthus altissima. European Invasive Alien Species Gateway. Available from http://www.europe-aliens.org/speciesFactsheet. do? Species Id=16970. Accessed 24th Mar 2021.

De Lillo, E., Panzarino, O., Loverre, P., Valenzano, D., Mattia, C., Marini, F., Augé, M., \& Cristofaro, M. (2017). New eriophyoid mites from Italy. IV. Mites associated with weed plants. Systematic and Applied Acarology, 22, 2256. https:// doi.org/10.1115/saa.22.12.15.

Ding, J. Q., Wu, Y., Zheng, H., Fu, W. D., Reardon, R., \& Liu, M. (2006). Assessing potential biological control of the invasive plant, tree-of-heaven, Ailanthus altissima. Biocontrol Science and Technology, 16, 547-566.

EPPO bulletin. (2019). PM 9/29 (1) Ailanthus altissima. EPPO Bulletin, 50, 148-155. https://doi.org/10.1111/epp.12621.

EPPO (2021). EPPO global database. https://gd.eppo.int/. Accessed on 24th Mar 2021.

Heisey, R. M. (1996). Identification of an allelopathic compound from Ailanthus altissima (Simaroubaceae) and characterization of its herbicidal activity. American Journal of Botany, 83, 192-200.

Higgins, D., Thompson, J., Gibson, T., Thompson, J. D., Higgins, D. G., \& Gibson, T. J. (1994). CLUSTAL W: Improving the sensitivity of progressive multiple sequence alignment through sequence weighting, position-specific gap penalties and weight matrix choice. Nucleic Acids Research, 22, 4673-4680.

Hong, X. Y., \& Xue, X. F. (2005). Four new species of Aculops Keifer (Acari: Eriophyoidea: Eriophyidae) from China. Oriental Insects - Oriental Insects, 39, 203-211.

Hu, S. (1979). Ailanthus. Arnoldia, 39, 29-50.

iNaturalist (2021). Tree of Heaven (Ailanthus altissima). [24 March 2021]. Available from:https://www.inaturalist.org/ taxa/57278-Ailanthus-altissima.

Kiviat, E. (2004). Occurrence of Ailanthus altissima in a Maryland freshwater tidal estuary. Castanea, 69, 139-142.

Kowarik, I. (1983). Colonization by the tree of heaven (Ailanthus altissima) in the French Mediterranean region (Bas-Languedoc), and its phytosociological characteristics. Phytocoenologia, 11, 389-405.

Kowarik, I., \& Säumel, I. (2007). Biological flora of central Europe: Ailanthus altissima (Mill.) swingle. Perspectives in Plant Ecology, Evolution and Systematics, 8(4), 207-237.

Kumar, S., Stecher, G., Li, M., Knyaz, C., \& Tamura, K. (2018). MEGA X: Molecular Evolutionary Genetics Analysis across computing platforms. Molecular Biology and Evolution, 35, 1547-1549.

Landenberger, R. E., Kota, N. L., \& McGraw, J. B. (2007). Seed dispersal of the non-native invasive tree Ailanthus altissima into contrasting environments. Plant Ecology, 192, 55-70.

Lin, L. J., Peiser, G., Ying, B. P., Mathias, K., Karasina, F., Wang, Z., Itatani, J., Green, L., \& Hwang, Y.-S. (1995). Identification of Plant Growth Inhibitory Principles in Ailanthus altissima and Castela tortuosa. Journal of Agricultural and Food Chemistry, 43, 1708-1711.

Lin, F. P., Jin, C., \& Kuang, H. Y. (1997). A new genus and six new species of Eriophyidae from China (Acari:Eriophyoidea). Acta Entomologica Sinica, 40(1), 8693.

Marini, F., Weyl, P., Vidović, B., Petanović, R., Littlefield, J., Simoni, S., de Lillo, E., Cristofaro, M., \& Smith, L. (2021). Eriophyid mites in classical biological control of weeds: Progress and challenges. Insects, 12. https://doi.org/10. 3390/insects12060513.

Motard, E., Dusz, S., Geslin, B., Akpa-Vincesla, S. M., Hignard, C., Babiar, O., Clair-Maczulajtys, D., \& Michel-Salzat, A. (2015). How invasion by Ailanthus altissima transforms soil and litter communities in a temperate forest ecosystem. Biological Invasions, 17, 1817-1832.

Pisuttu, C., Marchica, A., Bernardi, R., Calzone, A., Cotrozzi, L., Nali, C., Pellegrini, E., \& Lorenzini, G. (2020). Verticillium 
wilt of Ailanthus altissima in Italy caused by $V$. dahliae new outbreaks from Tuscany. iForest, 13, 238-245. https://doi. org/10.3832/ifor3238-013.

Ripka, G., \& Érsek, L. (2014). A new Aculops species (Acari: Prostigmata: Eriophyoidea) on Ailanthus altissima from Hungary. Acta Phytopathologica Entomologica Hungarica, 49(1), 4956.

Shah, B. (1997). The Checkered Career of Ailanthus altissima. Arnoldia, 57(3), 21-27. Accessed Feb 16th 2021.

Sheppard, A. W., Shaw, R. H., \& Sforza, R. (2006). Top 20 environmental weeds for classical biological control in Europe: A review of opportunities, regulations and other barriers to adoption. Weed Research, 46, 93-117.

Skoracka, A., Kuczyński, L., de Mendonca, R., Dabert, M., Szydło, W., Knihinicki, D., Truol, G., \& Navia, D. (2012a). Cryptic species within the wheat curl mite Aceria tosichella (Keifer) (Acari, Eriophyoidea) revealed by mitochondrial, nuclear and morphometric data. Invertebrate Systematic, 26, 417-433.

Skoracka, A., Kuczyński, L., Szydło, W., \& Rector, B. (2012b). Data from: the wheat curl mite Aceria tosichella (Acari: Eriophyoidea) is a complex of cryptic lineages with divergent host ranges: evidence from molecular and plant bioassay data. Dryad Digital Repository. https://doi.org/10.5061/ dryad.sq63c.
Sladonja, B., Sušek, M., \& Guillermic, J. (2015). Review on Invasive Tree of Heaven (Ailanthus altissima (Mill.) Swingle) Conflicting Values: Assessment of Its Ecosystem Services and Potential Biological Threat. Environmental Management, 56(4), 1009-34.

Swingle, W. T. (1916). The early European history and the botanical name of the Tree of Heaven, Ailanthus altissima. Journal of the Washington Academy of Sciences, 6, 490-498.

Wickert, K. L., O'Neal, S. E., Davis, D. D., \& Kasson, M. T. (2017). Seed Production, Viability, and Reproductive Limits of the Invasive Ailanthus altissima (Tree-of-Heaven) within Invaded Environments. Forests, 8, 226.

Xue, X. F., \& Hong, X. Y. (2005). A taxonomic study on the genus Aculus Keifer from China (Acari: Eriophyoidea: Eriophyidae) with a description of six new species. Transactions of the American Entomological Society, 131, 387-401.

Publisher's note Springer Nature remains neutral with regard to jurisdictional claims in published maps and institutional affiliations. 